\author{
WOJCIECH HOFMAŃSKI \\ Uniwersytet Karola w Pradze \\ (Uniwersytet im. Adama Mickiewicza w Poznaniu)
}

\title{
ADAPTACJA I POROZUMIENIE. KOMUNIKACJA DWUJEZZYCZNA W EUROPIE ŚRODKOWEJ
}

\section{Wprowadzenie - Europa Środkowa}

Wykorzystywanie pojęcia Europa Środkowa jako wskaźnika zakresu badań jest działaniem w pewien sposób obarczonym ryzykiem. Nie należy bowiem zapominać, że ten atrakcyjny i popularny - choć stosunkowo młody ${ }^{1}$ - termin doczekał się w literaturze przedmiotu wielu opracowań, które pośrednio i bezpośrednio odnoszą się do terytorium (por. Bański 2008), a także uwarunkowań historycznych (por. Davis 1998; Szücs 1995), kulturowo-językowych (por. Newerkla 2007) czy społecznych (por. Bocheńska-Seweryn, Grotowska-Leder, Stanek 2003). Jednak nawet - przynajmniej do pewnego stopnia wyjściowa - perspektywa regionalno-terytorialna rodzi trudności interpretacyjne w związku ze współwystępowaniem różnych wariantów opisów geograficznych ${ }^{2}$. Zajmująca się tą problematyką Marta Cobel-Tokarska stwierdza wręcz, że Europa Środkowa to termin $w$ pewnym sensie pozbawiony konkretnego geograficznego desygnatu, ale przecież zwiazany z geografia bardzo ściśle (Cobel-Tokarska 2013: 172), natomiast cechą wspólną większości koncepcji jest brak możliwości ostatecznego zdefiniowania i ustalenia granic Europy Środkowej (Cobel-Tokarska 2013: 180). W konsekwencji zmusza to kolejnych badaczy do nieomal każdorazowego zajmowania stanowiska wobec istniejących definicji

\footnotetext{
${ }^{1}$ [Etapy funkcjonowania pojęcia] Idea Europy środkowej, która zakłada istnienie pewnej wspólnoty opierającej się na towarzyszącej geograficznemu sąsiedztwu wspólnocie doświadczeń, sięga korzeniami XIX wieku. Pojęcie to odnaleźć w pracach niemieckiego ekonomisty Friedricha Lista (por. Henderson 2004). Drugi etap funkcjonowania pojęcia można by określić mianem „niemieckiego”, co wiązać należy z politologiczną koncepcją germańskiej dominacji Fredricha Naumanna (Naumanna 1915), w której - co szczególnie interesujące z perspektywy lingwistycznej - popierał obok germanizacji również madziaryzację. Swoisty renesans myślenia o wspólnocie środkowoeuropejskiej przynoszą jednak lata osiemdziesiąte dwudziestego wieku (Kundera 1984), przy czym rok 1989 uznać można za cezurę, po której następują w obrębie kolejnych dyscyplin - nie tylko na gruncie polskim - próby redefinicji (por. Andruchowycz, Stasiuk 2001; Newerkla 2007).

2 [Europa Środkowa w perspektywie klasyfikacji geograficznych] Problematyką tą szczegółowo zajmował się Jerzy Bański, który analizował pozycję Polski i Europy Środkowo-Wschodniej (sic!) z perspektywy klasyfikacji amerykańskich, brytyjskich i polskich (Bański 2008).
} 
i koncepcji lub przynajmniej względnie precyzyjnego omówienia własnego punktu widzenia - zwłaszcza w odniesieniu do reprezentowanej dyscypliny naukowej.

\section{Językowa specyfika Europy Środkowej}

Nie inaczej jest w kontekście badań językowych. Z perspektywy lingwistycznej Europę Środkową tworzy mozaika kilku(nastu) lingwokultur, które w procesie historycznego rozwoju podlegały nieustannym kontaktom, tworząc dzięki temu swoistą nową jakość odróżniającą ten obszar od rejonów sąsiednich. Sama ling wokultura (linguaculture) to termin mający swoje korzenie w amerykańskim dyskursie antropologicznym (Agar 1994: 94) i odnoszący się do języka, którego granic nie stanowią jedynie kolejne podsystemy i ich realizacje w praktyce komunikacyjnej, ale którego integralną częścią jest szeroko rozumiana kultura - w tym również zwyczaje czy stereotypy. Koncepcja ta podkreśla więc znaczenie nierozerwalnej więzi, która wynika $\mathrm{z}$ faktu, że język jest zarówno nośnikiem, jak i budulcem kultury danej społeczności ${ }^{3}$. Kluczową kwestią pozostaje jednak bezpośrednie wskazanie w komunikacyjno-językowej przestrzeni regionu owej nowej jakości, która realnie konstytuowałaby jego odrębność. Na szczególną uwagę zasługuje w tym kontekście koncepcja środkowoeuropejskiej (dunajskiej) ligi językowej (zob. Kurzová 1996) - wciąż jeszcze stosunkowo słabo znana na gruncie rodzimego językoznawstwa slawistycznego czy polonistycznego. W ujęciu tym Europę Środkową wyznacza zasięg lingwokultur wchodzących $\mathrm{w}$ intensywną interakcję na obszarze dawnego imperium austro-węgierskiego, przy czym - jak jednoznacznie podkreśla Stefan Michael Newerkla (Newerkla 2007: 271) w przeciwieństwie do języka niemieckiego, węgierskiego, czeskiego i słowackiego funkcjonujący w tym układzie język polski i język słoweński określany mogą być mianem peryferyjnych ${ }^{4}$. Tym, co wyróżnia języki ligi środkowoeuropejskiej, jest natomiast5:

- akcent inicjalny;

- iloczas relewantny fonologicznie;

- produktywna prefiksacja czasownikowa;

- system trzech czasów gramatycznych;

- syntetyczna fleksja nominalna.

3 Więcej na ten temat w kontekście kształcenia regionalnego - zob. Hofmański, Pospiszil w druku.

${ }^{4}$ Co ciekawe, taka perspektywa obszarowa w znacznym stopniu pokrywa się (choć z pominięciem elementu słoweńskiego) z listą tych krajów, które stanowią najbardziej stały element w przypadku prób zestawienia różnych koncepcji. W ten sposób środkowoeuropejski status (wschodnich) Niemiec, Słowenii, krajów bałtyckich, zachodniej Ukrainy, a nawet Polski nie okazuje się oczywisty. Kwestionowanie środkowoeuropejskości Czech, Słowacji oraz Węgier praktycznie jest marginalne. Osobnym zagadnieniem jest jednak status Austrii, który w perspektywie lingwistycznej wiązać można policentrycznością lingwokultury niemieckiej w opozycji do praktycznie monocentrycznego języka czeskiego, słowackiego, węgierskiego, a także polskiego.

${ }^{5}$ Odmienne perspektywy interpretacyjne środkowoeuropejskiej ligi językowej szczegółowo rekonstruuje praski lingwista Jiří Januška w dysertacji Porovnávání středoevropských jazyků: za horizont strukturních rysủ a lexikálních prejímek, a przytoczone w niniejszym artykule zestawienie stanowi rezultat przeprowadzonych przez niego analiz porównawczych kolejnych koncepcji teoretycznych (zob. Januška 2017: 107). 
Jedną z najważniejszych przyczyn powstawania ligi językowej ${ }^{6}$ jest prawdopodobnie powszechna obecność zjawiska wielojęzyczności w zakresie kodów przynależących do różnych rodzin językowych oraz towarzyszący temu code switching oraz code mixing, co z kolei umożliwia migrację nie tylko elementów leksykalnych, ale i całych struktur konceptualizacyjnych (Januška 2017: 187-189), choć to jednak leksyka jest często przedmiotem szczególnego zainteresowania -

Częstą (po części świadomą, po części nieuświadamianą) motywacją dla przyjęcia obcego słowa do języka jest na przykład równoczesne przyjęcie tego, co nazywa się tym nowym słowem, np. nowe urządzenia czy przedmioty, ale także postawy, opinie i odkrycia, dalej potrzeba modyfikacji czy zwiększenia rozróżnianych możliwości języka, a wreszcie również mieszanie się języków i dialektów, wzajemne polityczne i ekonomiczne relacje czy próby osiągnięcia większego prestiżu społecznego. Przy normalnym rozwoju społeczeństwa przyrost liczby słów jest zawsze większy niż liczba słów znikających, dlatego w biernym zasobie słownictwa utrzymują się również słowa już nieużywane. $Z$ tego powodu zasób słownictwa to ogromnej wartości obraz przeszłości danej społeczności językowej. Z zapożyczeń a także kalek językowych można więc z reguły dobrze wyczytać również kulturowe wpływy, które na dany obszar językowy oddziaływały czy oddziałują. W środkowoeuropejskim kontekście uderzające sią przede wszystkim świadectwa kulturowego kontaktu Bałtów, Słowian, Węgrów z przedstawicielami niemieckojęzycznej wspólnoty etnicznej (Newerkla 2007: 276; thum. z języka czeskiego W.H.).

Intensywne kontakty - a zwłaszcza przenikanie się podsystemów leksykalnych sąsiadujących języków, które jednocześnie przynależą do różnych rodzin - nie wyczerpują jednak specyfiki językowej interakcji w Europie Środkowej. Drugim, równolegle funkcjonującym fenomenem, który wpływa na odrębność regionu, jest bowiem komunikacja dwujęzyczna. Jak jednak wygląda relacja obu tych fenomenów?

\section{Komunikacja dwujęzyczna}

Komunikacja dwujęzyczna w szczególny sposób stoi w opozycji do obecnego na tym obszarze multilingwizmu, co jednak nie oznacza, że oba zjawiska konstytuujące językową specyfikę regionu nie mogą współwystępować. Opozycyjność wynika bowiem z wciąż powszechnie obserwowanych odmiennych strategii komunikacyjnych obieranych przez mieszkańców Europy Środkowej. W przypadku komunikacji dwujęzycznej następuje bowiem rezygnacja z języka wspólnego, czyli żaden z uczestników aktu komunikacji nie decyduje się na próbę dostosowania się i przejścia na relatywnie znany mu - choćby właśnie dzięki długotrwałej interakcji - język obcy (będący jednocześnie językiem pierwszym interlokutora). Taka specyfika dostrzegalna jest wciąż na poziomie współczesnej komunikacji czesko-słowackiej również w przypadku kontaktu różnojęzycznych osób żyjących jednak we wspólnej przestrzeni, co pozornie wskazywałoby na dominującą pozycję jednego z kodów językowych. Czasem wręcz sprawna i efektywna komunikacja przebiega w sytuacji braku jakiegokolwiek wspólnego języka trzeciego. Z kolei osoby cechujące się multi-

${ }^{6}$ Przyjmuje się, że liga językowa jest wytworem interakcji przynajmniej trzech systemów. W kontekście Europy Środkowej fenomen ten dotyczy języka niemieckiego, węgierskiego oraz pozostających z nimi w intensywnych kontaktach języków słowiańskich. Na strukturę tę nakłada się także język romski i jidysz. 
lingwizmem obejmującym języki przynależące do różnych rodzin dostosowują się do swojego interlokutora na zasadzie doboru optymalnego kodu także wówczas, gdy obaj interlokutorzy mają do dyspozycji wspólny (choć nienatywny) język trzeci. Słowaccy i czescy studenci polonistyki praktycznie nie wykorzystują znanego sobie języka obcego. Metoda obserwacji uczestniczącej umożliwia także jednoznaczne stwierdzenie, że wychowane na południu Słowacji osoby pochodzenia węgierskiego, w codziennym kontakcie z natywnymi użytkownikami języka czeskiego również bardzo często za optymalną strategię uznają komunikację dwujęzyczną. Co więcej, praktyka komunikacyjna wskazuje, że natywni użytkownicy polszczyzny mogą być włączeni do takiego aktu komunikacji na pełnoprawnych zasadach, co jednak - w przeciwieństwie do w zasadzie bezwarunkowej komunikacji czesko-słowackiej - najczęściej uzależnione jest od przynajmniej elementarnej znajomości języka polskiego jako obcego w przypadku natywnych użytkowników języka czeskiego i słowackiego. Należy jednak odnotować, że badania w zakresie językowych relacji czesko-słowackich wskazują na asymetrię, która wynika ze zmniejszającej się obecności języka słowackiego w czeskiej przestrzeni lingwokulturowej (zob. Nábělková 2008: 310-311).

Komunikacja dwujęzyczna nie okazuje się zatem zjawiskiem związanym wyłącznie z klasyfikacją genetyczną języków Europy Środkowej. Wydaje się - choćby ze względu na obserwowaną asymetrię - niemal pewne, że równie ważnym czynnikiem są aktualne uwarunkowania społeczne oraz indywidualne predyspozycje użytkowników języka (wynikające wprost z określonej świadomości językowej, rozumianej także jako powszechnie akceptowany potencjał komunikacyjny określonego języka ${ }^{7}$ ). Komunikacja dwujęzyczna, w przeciwieństwie do multilingwizmu opartego na stopniowalnych kompetencjach, opiera się na fenomenie komunikatywności ${ }^{8}$, który związany jest z procesami adaptacyjnymi zarówno w zakresie komunikacji mówionej, jak i pisanej - i to właśnie pisana odmiana języka stanowi w tym kontekście przedmiot szczególnego zainteresowania. Tym samym celem niniejszego artykułu jest łączna analiza obu tych aspektów stanowiących wciąż chyba najmniej znany element specyfiki językowych interakcji w Europie Środkowej.

We wskazanym regionie komunikacja dwujęzyczna jest zjawiskiem typowym przede wszystkim dla interakcji lingwokultur Słowian Zachodnich ${ }^{9}$. W tym kontekście niezwykle ważne pytanie dotyczy więc tego, w jaki sposób możliwe staje się uzyskanie porozumienia w sytuacji niewykorzystywania lub wręcz niedostępności wspólnego kodu językowego np. gdy obaj interlokutorzy są monojęzyczni lub lista znanych im języków się nie pokrywa. Punktem wyjścia okazać się może analiza porównawcza kategorii gramatycznych, któ-

${ }^{7}$ Więcej na temat ewolucji świadomości językowej Czechów i czesko-słowackich relacji językowych pisałem w artykule Ewolucja świadomości językowej Czechów po 1989 roku (Hofmański 2016).

${ }^{8}$ Bezpośrednią konsekwencją stawiania fenomenu komunikatywności w swoistej opozycji do multilingwizmu jest odrzucenie modelu bilingwizmu receptywnego jako sposobu interpretacji tego zjawiska. Jednak komunikację dwujęzyczną klasyfikowaną jako jeden z wariantów wielojęzyczności (obok koncepcji tak zwanej semikomunikatywności) można bez trudu odnaleźć w czesko- oraz słowackojęzycznej literaturze przedmiotu (por. Nábělková 2008: 93-102).

${ }^{9}$ Potencjał komunikacji dwujęzycznej nie zamyka się jednak wyłącznie w granicach słowiańszczyzny zachodniej. Otwarta bowiem pozostaje kwestia języka łemkowskiego czy współczesnych interakcji, które w ostatnich kilkunastu latach zintensyfikowały się w związku masową emigracją ekonomiczną z Ukrainy do Czech, Polski i na Słowację. Te interakcje nie doczekały się jednak jeszcze szczegółowych analiz. 
rymi operują systemy języka czeskiego, polskiego i słowackiego. W monumentalnej monografii Języki słowiańskie Hanna Dalewska-Greń (Dalewska-Greń 1997: 238-292) wskazuje na istnienie 10 kategorii gramatycznych (imiennych: liczby, rodzaju, przypadka, apelu, określoności; werbalnych: czasu, trybu, osoby, strony i finitywności) w 12 opisywanych przez siebie językach słowiańskich (polski, czeski, słowacki, górno- i dolnołużycki, rosyjski, białoruski, ukraiński, słoweński, macedoński, bułgarski oraz serbski i chorwac$\mathrm{ki}^{10}$ ). Jednak mimo najbliższego pokrewieństwa czeszczyzny, polszczyzny i języka słowackiego nie oznacza to, że kategorie te występują czy funkcjonują tak samo we wszystkich trzech systemach. Pewne niezgodności obserwowane są bowiem w zakresie fleksji imiennej. Systemowe różnice dotyczą kategorii apelu oraz kategorii rodzaju w odniesieniu do męskoosobowości i ściśle powiązanej z tym kategorii deprecjatywności, której jednak w swoim opracowaniu Hanna Dalewska-Greń nie uwzględniła, przyjmując - jak można się domyślać - nie tyle systemowo-kategorialną ${ }^{11}$, ile raczej funkcjonalno-stylistyczną interpretację zjawiska ${ }^{12}$.

Vocativus, interpretowany jako odrębny, morfologiczny środek w funkcji apelu, występuje w języku czeskim oraz polskim. W słowackim w funkcji apelatywnej występują nieomal wyłącznie formy homonimiczne $\mathrm{z}$ formami nominativu. Norma użytkowa języka polskiego sytuuje go więc ,w połowie drogi” między polskim i czeskim, choć również

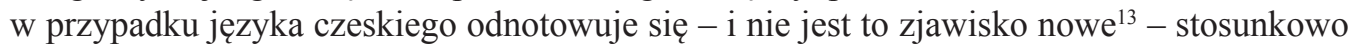
podobne wykorzystywanie nominativu. Specyfika kategorii apelu, a przede wszystkim jej określona funkcjonalność i kontekstowość, nie powoduje jednak realnych trudności percepcyjnych w przypadku komunikacji dwujęzycznej uwzględniającej ten element.

Nieobecna w języku czeskim opozycja rodzaju męskoosobowego i niemęskoosobowego realizowana jest natomiast przez język polski i (w bardzo wąskim zakresie) słowacki ${ }^{14}$. W słowackim męskoosobowe końcówki fleksyjne wariantywnie przyjmują także nazwy zwierząt: pes, vlk i vtak. Obok nich część badaczy w analogiczny sposób interpretuje hipokorystyczne nazwy zwierzęce na -o (Dalewska-Greń 1997: 247-248). Znów jednak odmienności te nie przekładają się wyraźnie na problemy komunikacyjne choćby ze względu na fakt, że wszystkie trzy języki dysponują zbieżnym zestawem końcówek gramatycznych mianownika l.mn. dla rzeczowników posiadających w liczbie pojedynczej rodzaj męski (por. pol. -y, -i, -e, -owie; czes. -y, -i, -é, -ove; słow. -y, -i, -í, -e, -ovia), co z perspektywy

${ }^{10}$ W swojej analizie Hanna Dalewska-Greń zdecydowała się literackie odmiany języka używane współcześnie przez Serbów i Czarnogórców, Chorwatów oraz bośniackich Muzułmanów (Bośniaków) opatrzeć terminem serbski/chorwacki. Jak zaznacza autorka, w opisie języków słowiańskich język serbski i język chorwacki powinny występować jako jedna jednostka opisu równa ranga pozostałym językom, zaś niewątpliwe różnice między nimi powinny być opisywane na poziomie „o stopień niższym” (Dalewska-Greń 1997: 13-14).

11 W nowszych opracowaniach stanowisko takie reprezentuje między innymi Mirosław Bańko (Bańko 2005: 59-60.

$12 \mathrm{~W}$ pochodzącej również z 2005 roku pracy opozycyjne stanowisko zajmuje natomiast Hanna Jadacka (por. Jadacka 2005: 20).

13 Już w okresie międzywojennym czescy językoznawcy dostrzegali zastępowanie form vacativu nominativem, ale tylko w mówionej odmianie języka (czes. hovorová čeština). Zjawisko to dotyczy przede wszystkim zdrobniałych imion żeńskich (Anka!) oraz niedeminutywnych form męskich antroponimów (Václav!), co uznawane jest za wpływ języka niemieckiego (Mathesius 1923).

${ }^{14}$ Opozycja ta realizowana jest również przez język górnołużycki. 
interpretacyjnej nienatywnego użytkownika w „najgorszym przypadku” oznaczać może niezamierzone wykorzystanie kategorii deprecjatywności, która jednak jest mocno ograniczona i każdorazowo związana z określonym kontekstem sytuacyjnym. Nawet tak fragmentaryczna analiza porównawcza systemów gramatycznych języka czeskiego, polskiego i słowackiego zdaje się dodatkowo potwierdzać, że trudności użytkowników blisko spokrewnionych języków we wzajemnej komunikacji mają inne podłoże - ich źródłem są bowiem odmiennie zachodzące procesy adaptacyjne o wyraźnie indywidualnym charakterze.

\section{Adaptacja i porozumienie}

Adaptacja prowadząca do porozumienia jest kuszącym przedmiotem badań lingwistycznych. By jednak uzyskać pełniejszy obraz tak fascynującego zjawiska jak komunikacja dwujęzyczna, konieczne jest odniesienie się zarówno do komunikacji ustnej, jak i (niestety nadal niebędącej w tym kontekście przedmiotem szczególnego zainteresowania językoznawców-slawistów) komunikacji pisemnej. Krótko powracając do psycholingwistycznych eksperymentów poświęconych czynnikom warunkującym rozumienie ustnych komunikatów w pokrewnym języku obcym, które realizowane były na płaszczyźnie czesko-polskiej ${ }^{15}$, należy podkreślić, że nowością jest w tym przypadku próba interpretacji badań nieograniczająca się jedynie do analizowanej pary, ale całego zjawiska komunikacji dwujęzycznej w Europy Środkowej.

Uczestnikami przywołanych badań była stosunkowo liczna, bo ponadstuosobowa grupa studentów. W głównej części eksperymentu na terenie Polski udział wzięło 101 precyzyjnie wyselekcjonowanych osób, których zadaniem była subiektywna ocena trudności rozumienia komunikatu w nieznanym języku pokrewnym. Respondenci podzieleni zostali na dwie grupy. Ten sam tekst prezentowany był grupie przez natywnego użytkownika języka grupy, a w drugim przypadku przez natywnego użytkownika języka komunikatu. Analizowaną zmienną był bowiem wpływ akcentu wyrazowego na poziom percepcji ${ }^{16}$. Poza wskazaniem odczuwalnego poziomu trudności (skala szkolna 1-6) badani musieli także odpowiedź na 5 pytań kontrolnych. Pytania pozwoliły zweryfikować, czy subiektywnie oceniany poziom trudności realnie przekładał się na możliwość dotarcia do wartości informacyjnej obcojęzycznego komunikatu. Okazało się, stały akcent inicjalny języka czeskiego wyraźnie utrudnił zadanie grupie, której tekst prezentował prymarnie czeskojęzyczny lektor (4,52 w porównaniu ze średnią 3,9 w grupie kontrolnej), a odpowiedzi na zamknięte i otwarte pytania kontrolne bezspornie potwierdziły zasadność wskazywanego poziomu odczuwalnej trudności. W komunikacji dwujęzycznej oznacza to więc konieczność przystosowania słuchu fonologicznego, która staje się kluczowym czynnikiem warunkującym

15 Szerzej na ten temat - zob. Hofmański 2014: 46-89.

${ }^{16}$ Przyjęto założenie, że artykulacja głosek języka obcego przez natywnego i nienatywnego lektora nie będzie mieć bezpośredniego wpływu na percepcję, ponieważ ewentualne odstępstwa od normy ortofonicznej u nienatywnego użytkownika języka tekstu wynikają wprost z określonego słuchu fonologicznego, a problemy te są wspólne - a tym samym zneutralizowane - również w przypadku obu grup prymarnie polskojęzycznych uczestników eksperymentu, których słuch fonologiczny nie pozwala na fonologiczną interpretację nieobecnych lub pełniących w języku polskim jedynie funkcję alofonów czeskich fonemów. 
porozumienie w perspektywie czesko-polskiej i - analogicznie, ze względu na akcent inicjalny - słowacko-polskiej ${ }^{17}$. W przypadku relacji czesko-słowackiej podobna interpretacja nie jest więc możliwa, co częściowo wyjaśnia powszechność tego modelu, opartego prawdopodobnie jedynie na adaptacji semantycznej (kontekstowej interpretacji nieznanych leksemów). Jednocześnie może to sugerować wyższość czynnika prozodycznego nad leksykalnym w odniesieniu do recepcji autentycznych komunikatów (niezawierających celowo nagromadzonej pozornej ekwiwalencji leksykalnej). Teza ta wymaga dodatkowych badań uwzględniających także procentowy udział leksyki ogólnosłowiańskiej w tzw. słownikach minimum poszczególnych języków, a także roli kontekstu komunikacyjnego. Należy jednak z całą mocą podkreślić, że nawet relacja podsystemów leksykalnych czeszczyzny i języka słowackiego - mimo znacznego stopnia zgodności - nie jest wolna od problemów wynikających z wyraźnych odmienności, co naturalnie przywodzi na myśl analogiczne relacje z podsystemem leksykalnym polszczyzny:

Wysoki stopień leksykalnej zgodności, biwalencja środków leksykalnych łączy się, jak wiemy, z genetycznym pokrewieństwem naszych [słowackiego i czeskiego - przyp. W.H.] języków jak również z kontaktowym, historycznym rozwojem, z długookresowym funkcjonowaniem czeszczyzny jako języka kultury w słowackiej przestrzeni i jej leksykalnym wpływom przy odrodzeniowym rozwijaniu zasobu słownictwa, a wreszcie także (często ukierunkowanym) paralelnym rozwojem leksyki w dobie wspólnego państwa. W przypadku różnic leksykalnych chodzi o zjawiska $\mathrm{z}$ licznych zakresów. Jeden $\mathrm{z}$ nich to różnice wynikające $\mathrm{z}$ różnych procesów rozwojowych genetycznie wspólnego słownictwa prasłowiańskiego - w różnicach odzwierciedla się trychotomiczny podział języka słowackiego z „środkowosłowakizmami” odmiennymi od zachodniosłowiańskiego zakresu słownictwa - ich występowanie w literackiej odmianie języka słowackiego i częsta synonimiczność z jednostkami nieśrodkowosłowackiego pochodzenia stanowi źródło słowackiej leksykalnej synonimii odmiennej od czeszczyzny. Dalsze istotne różnice wynikają z innego występowania słów obcych, innych tendencji motywacyjnych, a także z odmiennego podejścia do zapożyczeń rozlicznej proweniencji, w których odzwierciedla się historyczne przyporządkowanie do różnych struktur państwowych w przeszłości. Nie chodzi przy tym o prostą projekcję wyobrażeń o śladach ważnych historycznych związków język słowacki - język węgierski, język czeski-język niemiecki, chociaż niewątpliwie te powiązania i wynikające z nich różnice w zasobie słownictwa istnieją. (Nábělková 2008: 175-176; tłum. z języka słowackiego W.H.)

Jak wiadomo, na kształt systemu leksykalnego polszczyzny największy wpływ miał język niemiecki, czeski oraz łacina - z nich wywodzi się najliczniejsza grupa utrwalonych zapożyczeń leksykalnych, co można interpretować jako sytuację potencjalnie sprzyjającą wciąż efektywnej komunikacji dwujęzycznej w kontakcie z rodzimymi użytkownikami języka czeskiego i słowackiego. Tym, co mogłoby wyróżniać rozwój polskiej leksyki W perspektywie środkowoeuropejskiej byłby - jak się wydaje - głównie rusycyzmy. Te jednak (mimo braku geograficznej bliskości i bezpośredniego kontaktu systemów - rów-

17 Eksperyment potwierdził, że odmienne cechy prozodyczne, które są ściśle związane z wieloelementowymi segmentami fonologicznymi komunikatu, wpływają na poziom zrozumiałości komunikatu mówionego. Czynnikiem wpływającym na zaburzenia komunikacyjne jest akcent wyrazowy, który stanowi wykładnik fonologicznych cech konfiguracyjnych (a dokładnie demarkacyjnych) - tym samym zaburzenie percepcji delimitacyjnych funkcji dźwięków przekłada się na zablokowanie działania mechanizmów poznawczych, które dają możliwość interpretacji znaczeń wspólnych (lub przynajmniej analogicznych) morfemów i leksemów współwystępujących w blisko spokrewnionym systemie czeszczyzny czy języka słowackiego. W ten sposób koncentracja interlokutorów na formie a nie samej treści komunikatu utrudnia proces komunikacji (zob. Hofmański 2014: 85). 
nież wpłynęły na czeszczyznę w dobie odrodzenia narodowego, kiedy wraz z zapożyczeniami polskimi uzupełniały zasoby odtwarzanego języka.

Komunikację dwujęzyczną w wariancie ustnym można więc uznać za szczególny przykład procesu adaptacji. Czy pojęcie to równie dobrze opisuje to, co dostrzec można w odniesieniu do pisanej odmiany języka? Odpowiedź na tak postawione pytanie musi być twierdząca. Opracowana - początkowo z myślą o pokrewnych językach romańskich technika siedmiu sit (McCann, Klein, Stegmann 2003) jest bowiem szczegółowym opisem optymalnej strategii adaptacyjnej. Na czym polega przywołana metoda?

Punktem wyjścia stało przekonanie autorów o malejącej efektywności komunikacji transkulturowej przy wykorzystaniu języka trzeciego:

Nigdy wcześniej, nawet w „międzynarodowym” średniowieczu czy pod rządami imperium rzymskiego, Europa nie doświadczyła takiej intensywności wzajemnej wymiany i kontaktów w handlu i przemieszczaniu się - podobnie jak w przypadku mediów rozrywkowych i informacyjnych. [...] Spotkamy coraz więcej Europejczyków mówiących innymi językami. Korzystanie z języka trzeciego (lingua franca) jest samo w sobie jest procesem dystansującym - nie może zwiększyć bliskości, jakiej oczekujemy od takich kontaktów: ponieważ żaden z interlokutorów nie korzysta z własnych języków, nikt nie jest w stanie „sprostać” wyzwaniom na obcym gruncie. Europejczycy coraz bardziej zdają sobie sprawę z wartości języków ojczystych kontekście przekazywania pełnego znaczenia, ale generalnie unikają wkładania czasu i wysiłku wymaganego do zdobycia kompetencji komunikacyjnych w kilku językach europejskich (McCann, Klein, Stegmann 2003: 7; thum z języka angielskiego W.H.).

Na bazie takiego przeświadczenia została opracowana technika nawiązująca do ograniczonej, ale wciąż możliwej wzajemnej zrozumiałości języków należących do tej samej rodziny ${ }^{18}$. Na podstawie akademickiej praktyki glottodydaktycznej wyznaczono i kompleksowo omówiono siedem kroków (,sit”) w analizie tekstów pisanych, których przejście ma umożliwić dotarcie do wartości informacyjnej komunikatu - stąd właśnie nazwa metody.

W przypadku języków romańskich kolejne sita to: słownictwo internacjonalne (1), słownictwo panromańskie (2), odpowiedniki fonetyczne (3), pisownia i wymowa (4), panromańskie struktury syntaktyczne (5), elementy morfologiczno-syntaktyczne (6), prefiksy i sufiksy (7). Analogiczny program dla obszaru słowiańskiego (zob. Zybatow 2003) jest nadal rozwijany (Golubovic, Gooskens 2015: 369), co nie wyklucza własnych propozycji opartych na interakcyjnych doświadczeniach w słowiańskiej części Europy Środkowej. Wydaje się przy tym bardzo prawdopodobne, że (przynajmniej zachodnio-) słowiańska perspektywa pozwoliłaby w niewielkim stopniu ograniczyć liczbę kroków niezbędnych do osiągnięcia porozumienia (wyizolowania wartości informacyjnej komunikatu pisanego). Tego typu propozycja musi zawierać elementy wspólne z pierwotną koncepcją siedmiu sit $(1,2,4,7)$ elementy zmodyfikowane (5) oraz elementy nowe, zgodne ze słowiańską specyfiką. W ten sposób powstaje lista obejmująca sześć zagadnień, których nawet pobieżna znajomość efektywnie ułatwi analizę obcojęzycznego komunikatu, a tym samym osiągnięcie porozumienia:

- słownictwo internacjonalne;

- słownictwo (ogólno-)słowiańskie;

${ }_{18}$ Pierwsza prezentacja naukowa projektu miała miejsce już we wrześniu 2000 (35th Linguistic Colloquium at the Innsbruck University). 
- analogie w zakresie pisowni i wymowy;

- układ linearny wypowiedzeń i jego możliwe modyfikacje;

- kategorie werbalne i imienne;

- prefiksy i sufiksy.

Przedstawiona propozycja uwzględnia prawdopodobnie wszystkie elementy, których łączne wykorzystanie pozwoli zwiększyć efektywność analizy tekstu w najbliżej spokrewnionym języku zachodniosłowiańskim. Przy stosunkowo dużej uniwersalności metody należy jednak wziąć jednak pod uwagę, że trzeci ze wskazanych punktów (analogie w zakresie pisowni i wymowy) stanowiłby pewną metodyczną przeszkodę w perspektywie wykorzystywania techniki w zakresie kontaktów wykraczających poza zachodnią część słowiańszczyzny, co oczywiście wiązać trzeba zasięgiem alfabetu łacińskiego. Kolejna uwaga związana jest bezpośrednio z liczbą słowiańskich „sit”. Istnieje bowiem możliwość rozdzielenia ostatniego z nich na dwa niezależne (prefiksy oraz sufiksy). Dzięki tej niewielkiej modyfikacji, uwzględniono by $-\mathrm{z}$ jednej strony - specyfikę słowiańskiej kategorii aspektu (co jednocześnie stanowi trafne uzasadnienie takiej decyzji), z drugiej strony zaś zachowanie oryginalnej liczby siedmiu sit stanowi ukłon w kierunku twórców metody i pozawala - nawet na poziomie terminologicznym - na czytelne wskazanie źródła inspiracji. Ich ostateczna liczba i układ przedstawia się zatem następująco:

1. Słownictwo internacjonalne;

2. Słownictwo (ogólno-)słowiańskie;

3. Analogie w zakresie pisowni i wymowy;

4. Kategorie werbalne i imienne;

5. Układ linearny wypowiedzeń i jego możliwe modyfikacje;

6. Prefiksy;

7. Sufiksy.

Słownictwo internacjonalne (1) podobnie jak wspólne (2) - a więc doskonale znane i zrozumiałe - słownictwo słowiańskie jest oczywistym „drogowskazem”, dzięki któremu nieznający języka pokrewnego czytelnik może odnaleźć się w komunikacyjnym przekazie. W takim samym stopniu dotyczy to tego, co wspólne „lokalnie” (słownictwa słowiańskiego) oraz tego, co wspólne dla większej liczby europejskich wspólnot językowych. Oczywiście istnieje ryzyko występowania zjawiska pozornej ekwiwalencji (co warte podkreślenia: zarówno w jednym jak i w drugim przypadku), jednak procentowy udział podobnych pułapek komunikacyjnych w stosunku do realnych ekwiwalentów pozwala na relatywnie bezpieczne wykorzystywanie tego elementu metody ${ }^{19}$. Kolejna płaszczyzna - analogie w zakresie pisowni i wymowy (3) - uwzględnia między innymi odmienne konwencje diakrytyczne/ortograficzne (por. czes./słow. $\check{s}$ oraz pol. $s z$, ale także regularne zjawiska na poziomie organizacji dźwiękowej języka: czes./słow. hora, hodina oraz pol. góra, godzi-

19 Nie bez znaczenia jest również rola kontekstu, który w znacznym stopniu może zneutralizować niebezpieczeństwo polegające na oddziaływaniu zjawiska pozornej ekwiwalencji. Trudno bowiem zakładać, że tego typu jednostki leksykalne będę występowały jedynie jako pozakontekstowe, wyizolowane i jednowyrazowe komunikaty. Należy przy tym podkreślić, że leksyka ogólnosłowiańska pochodzenia prasłowiańskiego szacowana jest na 1626 jednostek, a analogiczny katalog dla Słowian Zachodnich musi być znacznie bardziej rozbudowany. (Por. Nakonieczny 2010: 107) 
na). Następne sito (4) odnosi się do świadomości występowania praktycznie całkowicie zbieżnych kategorii gramatycznych, co umożliwi dostęp do konstrukcji eliptycznych lub choćby wypowiedzeń z podmiotem domyślnym ze wzglądu na możliwość intuicyjnego interpretowania funkcji kolejnych wyrazów tekstowych. Piąty element odnosi się natomiast do nieoczekiwanych przez rodzimych użytkowników języków zachodniosłowiańskich modyfikacji szyku (5) w zakresie znanych (i nieznanych) elementów (np. lokowanie czes. i słow. spójnika ale na dalszych pozycjach syntaktycznych czy też nieobligatoryjne umieszczanie zaimka zwrotnego się na drugiej pozycji syntaktycznej w przypadku wypowiedzeń polskich). Wydaje się przy tym prawdopodobne, że omówiona w punkcie czwartym zdolność intuicyjnego interpretowania funkcji gramatycznych wyrazów tekstowych stanowi w prostej linii uzasadnienie możliwości akceptowania tych nienaturalnych zmian na płaszczyźnie linearnej wypowiedzeń obcojęzycznych. Ostatnie dwa kroki (6 i 7) związane są ze znacznymi analogiami w zakresie formantów słowotwórczych, przy czym niezwykle istotna i kłopotliwa w procesie glottodydaktycznym, a jednocześnie intuicyjnie dostępna (w oparciu wyłącznie efekty akwizycji języka pierwszego) kategoria aspektu uzasadnia ich rozłączne traktowanie.

\section{Podsumowanie}

Niniejsza analiza pozwala z dużą dozą prawdopodobieństwa stwierdzić, że kluczem do efektywnego porozumiewania się użytkowników blisko spokrewnionych języków jest właśnie a daptacja rozumiana jako umiejętność zaakceptowania i wykorzystywania międzysystemowych analogii (komunikatywność) oraz neutralizowania określonego zestawu nieprzystawalności, co jednoznacznie odróżnia ją od stopniowalnej umiejętności (kompetencji) posługiwania się określonym językiem obcym niewykazującym obligatoryjnie daleko idących zbieżności systemowych. Zjawiska te, choć oczywiście mogą wchodzić we wzajemną interakcję (choćby w przypadku zaawansowanych procesów glottodydaktycznych obejmujących najbliżej spokrewnione języki), należy jednak traktować jako dwie odrębne strategie komunikacyjne - podobnie jak wielojęzyczność i komunikację dwujęzyczną jako dwa niezależne elementy świadczące wciąż o istnieniu językowego fenomenu środkowoeuropejskości. Jednocześnie nieograniczona do mikroperspektywy analiza kontaktu językowego (por. Januška 2017: 43-44) umożliwia pełniejszą interpretację międzyjęzykowych powiązań w Europie Środkowej ze względu na szersze, holistyczne spojrzenie - uwzględniające nie tylko stopień pokrewieństwa systemów czy intensywność i częstotliwość ich kontaktów na określonym terytorium, ale także specyficzne przekonania, które można sprowadzić do komunikacyjnych autostereotypów świadczących o subiektywnie odczuwanym potencjale porozumiewania się zbiorowości użytkowników danego języka (wspólnoty komunikatywnej). Pozwala to tym samym na rozpatrywanie fenomenu przez pryzmat bliskości genetycznej języków, lingwistyki arealnej (zob. Muysken 2008: 3-9) oraz psycholingwistyki związanej bezpośrednio z szerzej rozumianą świadomością językową.

Tato studie vznikla za podpory projektu Univerzity Karlovy Progres č. 4, Jazyk v proměnách času, místa, kultury.

This study was supported by the Charles University project Progres 4, Language in the shiftings of time, space, and culture 
Studium powstało dzięki wsparciu projektu Uniwersytetu Karola Progres 4, Język w przemianach czasu, miejsca, kultury.

\section{Bibliografia}

Agar M.H., 1994, Language Shock. Understanding The Culture Of Conversation, New York.

Andruchowycz J., Stasiuk A., 2001, Moja Europa. Dwa eseje o Europie zwanej Środkowa, Wołowiec.

Bańko M., 2005, Wyktady z polskiej fleksji, Warszawa.

Bański J., 2008, Polska i Europa Środkowo-Wschodnia w koncepcjach podziatu Europy, „Prace Geograficzne" Problematyka geopolityczna ziem polskich, 218, s. 121-134.

Bocheńska-Seweryn M., Grotowska-Leder J., Stanek T., 2003, Old and new poverty in post-communist Europe, Kraków.

Cobel-Tokarska M., 2013, Europa Środkowa - dawne i nowe znaczenie, w: A. Firkowska-Mankiewicz, T. Kanasz, E. Tarkowska (red.), Krótkie wykłady z socjologii. Kategorie, problemy, subdyscypliny, Warszawa, s. 172-192.

Dalewska-Greń H., 1997, Języki słowiańskie, Warszawa.

Golubovic J., Gooskens Ch., 2015, Mutual intelligibility between West and South Slavic languages, "Russ Linguist" 39, s. 351-373.

Davis N., 1998, Europa, Kraków.

Henderson W., 2004, Friedrich List: Economist and Visionary 1789-1846, Londyn.

Hofmański, W., 2016, Ewolucja świadomości językowej Czechów po 1989 roku, „Bohemistyka” 2, s. $169-180$.

Hofmański W., Pospiszil K., Pragmakulturowe granice gościnności - w druku.

Hofmański W., 2014, Transfer ujemny a norma językowa. Język polski w nauczaniu Stowian, Praga. Jadacka H., 2005, Kultura języka polskiego. Fleksja, stowotwórstwo, składnia, Warszawa.

Januška J., 2017, Porovnávání středoevropských jazyki̊: za horizont strukturních rysů a lexikálních prejímek, Praga- praca doktorska.

Kundera M., 1984, Zachód porwany albo tragedia Europy Środkowej, „Zeszyty Literackie” 5, s. $23-38$.

Kurzová H., 1996, Mitteleeuropa als Schprach areal, „Germanistica Pragensisa” 13, s. 57-73.

Mathesius V., 1923, Nominativ misto vokativu v hovorové češtině, „Naše řeč, ročník” (7), 5, s. 138-140.

McCann W.J., Klein H.G., Stegmann T.D., 2003, EuroComRom - The Seven Sieves: How to read all the Romance languages right away, wyd. 2 zmienione, Aachen.

Muysken P., 2008, Introduction: Conceptual and methodological issues in areal linguistics, w: P. Muysken (red.), From Linguistic Areas to Areal Linguistics, Amsterdam, s. 1-23.

Nábělková M., 2008, Slovenčina a čeština v kontakte. Pokračovanie príbehu, Praga-Bratysława.

Nakonieczny D., 2010, Stratyfikacja polskiej i zarazem ogólnosłowiańskiej leksyki pochodzenia prasłowiańskiego na tle zachodniosłowiańskim, „Slavia Occidentalis” 67, s. 107-126.

Naumanna F., 1915, Mitteleuropa, Berlin.

Newerkla S.M., 2007, Areály jazykového kontaktu ve střední Evropě a německo-český mikroareál ve východním Rakousku, „Slovo a slovesnost” 68, s. 171-286.

Szücs J., 1995, Trzy Europy, Lublin.

Zybatow L., 2003, EuroComSlav - A road to Slavic languages, "Wiener Slawistischer Almanach" 52, s. 281-295. 


\section{WOJCIECH HOFMAŃSKI}

\section{Adaptation and understanding. Bilingual communication in Central Europe}

\section{Summary}

Depending on the selected theoretical concept, Central Europe is a melting pot of several or over a dozen linguistic cultures which constantly interacted in the process of historical development. In this multi-national landscape, the presence of Slavs (Czechs, Poles, Slovaks as well as Lusatians, Kashubians or Lemkos) has been a constant element. The speakers have used two languages in a single act of communication which is a phenomenon of its own.

This understanding is a tempting area of linguistic research. This text is dedicated to bilingual communication of Slavs with special emphasis placed on the processes of adaptation based on obtaining information from texts in written language (the seven sieves technique).

Keywords: inter-comprehension, phonological adaptation, communication strategies, seven sieves technique. 